\title{
8
}

\section{THE COVID-19 PANDEMIC IN THE UNITED KINGDOM}

\section{A tale of convergence and divergence}

\author{
Paul Anderson
}

\subsection{Introduction}

The United Kingdom of Great Britain and Northern Ireland is a plurinational union state consisting of four parts: England, Wales, Scotland, and Northern Ireland. It has 66.8 million inhabitants, the vast majority of whom reside in England. As the largest nation, England accounts for approximately 85 per cent of the UK population (56.3 million), followed by Scotland (5.4 million), Wales (3.1 million), and Northern Ireland (1.9 million). The UK has an ageing population with circa 20 per cent of the population aged 65 years and over, many of whom live in rural and coastal areas. The urban population of the UK is about 56 million, while the rural population is approximately 11 million (ONS 2020a).

The plurinational nature of the UK state is manifest in the distinct and at times competing understandings of nation and statehood in the devolved territories (Scotland, Wales, and Northern Ireland), each of which has its own constitutional and political identity. In the late 1990s, a highly asymmetrical form of political devolution was implemented in Scotland, Wales, and Northern Ireland, while England, notwithstanding its status as the largest constituent nation, became a constitutional anomaly. Two decades after the implementation of devolution, 'the English question' continues to garner traction in territorial debates, but reforms to English governance remain limited; the UK government doubles up as both a UK-wide and English government.

The UK was one of the countries worst affected by the Covid-19 crisis in 2020. From the first case of infection on 31 January 2020 until 31 October of that year, it registered more than 46,000 deaths, the highest rate in Western Europe. ${ }^{1}$ Despite the warnings of the World Health Organization (WHO), the UK government was rather slow to respond to the threat of the crisis and sought to delay the implementation of social distancing measures until absolutely necessary. This delay was 
compounded by support among some officials for 'herd immunity', that is, the notion that allowing the virus to spread naturally would ultimately build up enough resistance in the population. After a public outcry and strong condemnation from medical experts, the UK government abandoned this approach in favour of social distancing measures and, ultimately, a state-wide lockdown.

The National Health Service (NHS) is the collective name for the four health systems of England, Scotland, Wales, and Northern Ireland. Health has been a devolved matter since 1999, but even prior to this, the health services in Northern Ireland and Scotland were managed by their respective territorial offices in the UK government. Safeguarding the NHS from being overwhelmed by the coronavirus pandemic was a primary reason advanced by the UK government in its moves to secure a state-wide lockdown on 23 March 2020. The government's slogan 'stay at home, protect the NHS, save lives' reflected this priority. In keeping with it, temporary hospitals were constructed, retired healthcare professionals returned to work, and thousands of non-emergency operations were cancelled to free up space in hospital wards.

Public support and appreciation for the NHS and its staff were shown through a weekly 'clap for carers' during the first wave of the pandemic. Likewise, Prime Minister Boris Johnson repeatedly praised the dedication of NHS staff, especially after he was admitted to hospital while suffering from the virus. Despite acknowledgment that the NHS weathered the first wave rather well, this success was overshadowed by a chronic shortage of personal protective equipment (PPE), a lack of testing capacity for NHS workers, and thousands of deaths in both hospitals and care homes.

This chapter examines the evolution of the UK response to the pandemic during the first wave from January to October 2020. At the time of writing, the UK was in the midst of a second wave of infections, but analysis of the first wave already reveals many of the dynamics and tensions within the devolved system that were continuing to gain traction in the second wave. The politics of the pandemic that played out during the first wave demonstrated the decentralised nature of the response in the UK, but while local capacity was harnessed at the national level (Scotland, Wales, and Northern Ireland), local capacity in English regions was generally stifled by ineffectual central government direction. The main findings show how the pandemic raised the profile of devolution more than any other event in the last two decades. It points, however, to a limp federal spirit, particularly in the context of collaboration, and underlines the urgency for new and more imaginative thinking to reform and rejuvenate the Westminstercentric model of intergovernmental relations (IGR).

\subsection{The constitutional and legislative framework}

The UK is neither a unitary nor federal state but a union of nations with autonomous executives and legislatures in Scotland, Wales, and Northern Ireland. The Scottish Parliament, Welsh Parliament, and Northern Irish Assembly follow 
the reserved-powers model of devolution, whereby legislative competence is granted in all areas not specifically 'reserved' in the respective statutes for each nation (Mitchell 2009).

In the two decades since the inception of devolution, the coronavirus pandemic is the biggest public health issue faced by all levels of government. In consonance with the devolution models in each territory, important jurisdictions affected by the pandemic - health care and education, to name just two - are the responsibility of the devolved governments in Scotland, Wales, and Northern Ireland. In England, the absence of a devolved institution means that the UK government is also the English government and thus the UK government's Department for Health and Social Care focuses largely on health policy in England, albeit some aspects of health policy (e.g., human fertilisation and surrogacy) remain 'reserved' to the UK government. Emergency powers dealing with public health infections are detailed in different legislative acts for the different nations: the Public Health (Control of Disease) Act of 1984 for England and Wales, the Public Health etc. (Scotland) Act of 2008, and the Public Health Act (Northern Ireland) of 1967. Other emergency legislation exists to deal with civil emergencies across the whole of the UK - the Civil Contingencies Act of 2004 - but this was developed to reflect the various devolution settlements, involving concordats of agreed frameworks for cooperation with each devolved nation.

In recent years, political devolution has been strengthened by the devolution of further competences as well as fiscal levers and has also involved processes of 'power transfer' in the shape of 'devolution city deals' in England (Sandford 2020: 26). Fiscal devolution remains fairly limited for all three devolved institutions, but each enjoys broad competence over important policy areas such as economic development, as well as responsibility in areas to contribute to economic growth, including transport and infrastructure. Nonetheless, the devolved governments have access to limited reserves, and the fiscal frameworks of the Scottish, Welsh, and Northern Irish governments place significant constraints on the borrowing powers of the devolved governments. Consequently, the devolved governments had and have limited capacity and resources to mitigate the economic impact of Covid-19.

\subsection{Preparedness for a national disaster: The institutional framework}

All four nations in the UK have existing legislation to manage the spread of infectious diseases. While legislation varies in the nations (except for England and Wales, which are covered by the same Act), the Acts share similar powers to prevent, protect, and control a significant risk to human health. Through a system of action and surveillance, these Acts endow government ministers, local authorities, and magistrates with powers to issue regulations to prevent onward transmission of infectious viruses. 
The Civil Contingencies Act of 2004 is the main piece of legislation for responding to national emergencies in the UK. This legislation provides a framework enabling public authorities to respond to a range of emergencies: environmental disasters, health pandemics, protests, and terrorist attacks. In line with the Act, government ministers can use emergency regulations to introduce sweeping powers to deal with an emergency, but these are qualified with legal and parliamentary safeguards to eschew disproportionate action. In lieu of invoking the Act to deal with the coronavirus pandemic, the UK government instead created new legislation. The Coronavirus Act of 2020, however, was more lenient in its requirements for parliamentary oversight.

All tiers of government in the UK have machinery in place to respond to issues of (national) emergency. At the apex of UK government machinery is the Civil Contingencies Committee (COBRA), a coordinating and decision-making body that brings together relevant personnel and authorities depending on the nature of the emergency. Located in the cabinet rooms of Whitehall, COBRA is essentially an intra-governmental rather than intergovernmental body. Coordination with the devolved administrations takes place when required, but COBRA is not an intergovernmental forum. The UK does not have a specific intergovernmental emergency committee; during the coronavirus pandemic, traditional intergovernmental structures were shunned in favour of COBRA and newly created ministerial structures (see Section 8.4.5).

\subsection{Rolling out measures to contain the pandemic}

The announcement of a UK-wide lockdown on 23 March 2020 was supported by all major political parties in the UK. Opposition parties, including Labour, the Scottish National Party (SNP), and the Democratic Unionist Party, all of which were in government in the devolved territories, supported the UK government's lockdown. Among the public, there was 'almost universal support' for a full lockdown 'with $93 \%$ of the public saying they were in favour of the decision' (McDonnell 2020). As the lockdown was extended over April, both political and public support remained strong. In early May, however, as the UK government eased restrictions in England, divergence in approaches came to light in the devolved nations, with growing criticism among political parties that the lockdown in England was being eased too soon. The main opposition party, Labour, sought to balance its concern with the timeline for easing measures with consistent criticism that the government's plans were vague and entailed unnecessary risk for workers being urged to return to work. This had the backing of trade unions, smaller parties such as the Greens, as well as the devolved governments.

The divergence in approach to the easing of lockdown in May 2020 reinforced the status of the devolved administrations as autonomous governments. To the surprise of some, politicians and commentators alike, the Scottish, Welsh, and Northern Irish governments did not follow suit in lifting restrictions, 
precipitating criticism and concern about cross-border cooperation and revealing a lack of knowledge about the powers of the devolved governments to set their own agendas and route-maps vis-à-vis lockdown. The devolved governments criticised the UK government's approach to easing lockdown, which was pursued without significant consultation with the devolved leaders and thus did not take into consideration the impact that lifting restrictions would have on other parts of the UK. The confusion created by the easing of restrictions in England was compounded by the Prime Minister himself, who in a televised speech on 10 May addressed the population as 'the Prime Minister of the United Kingdom - Scotland, England, Wales and Northern Ireland', failing to mention that the lifting of measures applied to England only (Johnson 2020b).

\subsubsection{Taking the initiative}

The first Covid-19 case was identified in England on 31 January 2020, followed by confirmed cases in Northern Ireland (27 February), Wales (28 February), and Scotland (1 March). On 2 March, the UK government convened COBRA to discuss the UK response to the pandemic. Recognising the scale of the pandemic and the need for cooperation between the different governments, the first ministers of Scotland, Wales, and Northern Ireland also attended COBRA meetings. The involvement of the devolved administrations heralded the beginning of a collaborative approach to tackling the pandemic across the UK. This included a Coronavirus Action Plan jointly published by the four governments on 3 March, devolved support in the form of the Sewel Convention for the UK government's Coronavirus Act (receiving royal assent on $25 \mathrm{March}$ ), and parallel announcements of key decisions, such as the lockdown announced on 23 March. ${ }^{2}$ The much-heralded 'four-nation approach' entailed unprecedented levels of cooperation and a degree of uniformity between the governments hitherto unknown. In a nod to the clear division of competences vis-à-vis policy jurisdictions such as health care and education, this was a decentralised response; uniformity did not entail centralisation.

As the government machinery reacted to increasing numbers of cases across the UK in early March, the UK government advised against 'non-essential' travel and gatherings in large groups and encouraged people to work from home. On $12 \mathrm{March}$, the Scottish government announced a ban on gatherings of more than 500 people, while elsewhere in the UK unnecessary social contact was discouraged. On $18 \mathrm{March}$, all four governments announced the closure of schools (to take effect from $20 \mathrm{March}$ ), while on 20 March bars, cafés, and restaurants were instructed to close. In a televised address on $23 \mathrm{March}$, the Prime Minister detailed further restrictions, including a stay-at-home order and the closure of non-essential shops as well as gyms, libraries, playgrounds, and places of worship (Johnson 2020a). Extra powers were rolled out to the police to enforce the strict measures. On 25 March, the Coronavirus Act of 2020 received royal assent and granted UK ministers broad legislative powers to respond quickly to the pandemic. 


\subsubsection{UK government action}

Analysis of the role of the UK government in managing the coronavirus pandemic necessitates discussion of its role as the government of the UK as well as England. Prior to the roll-out of preventative measures such as the lockdown on 23 March, the UK government played a coordinating role between all four nations to respond to the pandemic. As noted earlier, this included using Whitehall machinery such as COBRA. Several COBRA meetings were convened prior to the widespread transmission of Covid-19 and increased in frequency throughout March and April 2020.

In early March, the government's advice was limited to self-isolation for seven days for individuals who developed Covid-19 symptoms such as a continuous cough or fever. By mid-March, the period of self-isolation was doubled to 14 days and extended to all individuals within a household in the event that one occupant tested positive for the virus. On 16 March, Boris Johnson announced further measures, including encouraging people to work from home and the cessation of non-essential contact and unnecessary travel. One week later on 23 March, in coordination with the devolved governments, he announced the lockdown. All non-essential businesses were closed, including bars, pubs, and restaurants (except for those that could offer food delivery and take-aways); places of worship were closed except for reduced-capacity funerals; nurseries, schools, colleges, and universities were closed; recreational activities were curtailed, including the closure of playgrounds, cinemas, museums, and art galleries; social events such as weddings and baptisms were prohibited; people were ordered to work from home where possible; and a stay-at-home order was issued.

To mitigate the economic damage caused by the pandemic, the government which controls the lion's share of fiscal levers in the UK - played a leading role in supporting employers and employees affected by the pandemic. This included various schemes applicable across all four nations of the UK. On 20 March, Rishi Sunak, Chancellor of the Exchequer, announced the launch of the Coronavirus Job Retention Scheme to provide 80 per cent of employees' salaries up to GBP 2,500 a month for those unable to work due to the stay-at-home order, as well as the Coronavirus Business Interruption Loan Scheme to support small and medium-sized enterprises with 12 months of interest-free access to loans, overdrafts, and other financial assets. Further economic packages were rolled out, among them the Coronavirus Large Business Interruption Loan Scheme to support large businesses with finance up to GBP 50 million over three years; the Self-Employment Income Support Scheme to support self-employed individuals with grants; and value-added tax (VAT) and income tax deferrals (administered by Her Majesty's Revenue and Customs).

At an individual level, the UK government, which is responsible for employment rights and most benefits and social security, also implemented numerous measures: statutory sick pay was made available to people unable to work due to contracting Covid-19 or engagement in self-isolation or shielding; low-income 
self-employed people were given access to Universal Credit, a benefit to help with living costs; and Universal Credit and other Working Tax Credit benefits were increased.

Owing to competition between different NHS boards in the different parts of the UK in procuring necessary PPE, other medical equipment, and coronavirus testing kits, in early April the UK government took the lead in the coordination and distribution of PPE across the UK. The government also introduced various measures to ensure the mass roll-out of a vaccine if and when it became available, including research at the government's military research facilities at Porton Down.

On 10 May, after almost eight weeks of lockdown, the government announced a relaxation of restrictions in England. In a televised address to the whole of the UK, the Prime Minister announced a change in message from 'stay at home' to 'stay alert', unveiled a new Covid Alert System, and encouraged people with jobs that could not be done from home to return to work. In Scotland, Wales, and Northern Ireland, however, the devolved governments maintained the previous advice of 'stay at home' and kept lockdowns in force. The government announced plans for primary school pupils in England to return to school by 1 June 2020, but many local authorities took the decision to keep schools closed. Between June and July, rules for the retail and hospitality sectors were eased. From 15 June, non-essential shops reopened, while in early July, bars, restaurants, pubs, and hairdressers reopened, having to adhere to a one-metre-plus rule in line with social distancing.

The reopening of the hospitality and retail sectors marked a crucial moment in the government's economic-recovery phase. To spur on this recovery, on 8 July the Chancellor announced a cut in VAT from 20 per cent to 5 per cent for accommodation, hospitality, and tourism services. The government also launched the UK-wide 'Eat Out to Help Out' scheme from 3 to 31 August, offering diners a 50 per cent reduction in their bills at participating cafés, pubs, and restaurants. The scheme certainly boosted economic recovery, but with only a 2.1 per cent rise in gross domestic product (GDP) in August, it fell short of more optimistic expectations.

By September 2020, shoots of economic recovery were cut short by an increase in Covid case numbers and the looming threat of further local lockdowns. From 14 September, a 'rule of six' was introduced to limit gatherings of separate households. On 18 September, additional restrictions were announced in the North-east of England, including a ban on household mixing, and later rolled out to the Midlands, North-west of England, and West Yorkshire. By the end of the month, further restrictions applied across the rest of the UK, including a 22:00 closure for pubs and restaurants.

As case numbers continued to rise in October, the government introduced a new three-tier lockdown system in England to establish local and regional lockdowns and reopened several emergency hospitals constructed to deal with the first wave of the pandemic. By the end of the month, large parts of England (Greater Manchester, Lancashire, Liverpool city region, South Yorkshire, and 
Warrington) were under the strictest tier 3 restrictions. On 31 October, the Prime Minister announced that the exponential growth in cases necessitated a further lockdown for an initial period of four weeks (until 2 December). The second lockdown was not as restrictive as the first (schools and universities, for instance, remained open), but pubs, restaurants, leisure facilities, and nonessential shops were closed.

In line with trends across the world (see Griglio 2020), there was a strong shift towards executive rule to manage the growing threat the pandemic posed. As mentioned, the Coronavirus Act granted UK ministers broad legislative powers to respond quickly to the pandemic. In addition, pre-existing powers, such as those in delegated legislation (legislation made other than by Parliament, but with the authority of Parliament), were also used. This was done mainly through statutory instruments (SIs), which at the end of October amounted to more than 282. As analysis by the Hansard Society (2020) has shown, 69 per cent of SIs used the 'made negative' procedure, which does not require parliamentary approval for the measure to come into force. The wide discretion given to the government to implement emergency measures came under greater scrutiny as the lockdown was eased, but, even so, further measures were introduced (e.g., the mandatory wearing of face masks), while the boundaries were blurred between what was law (and thus legally enforceable) and what was government guidance (Select Committee on the Constitution 2020).

With the resumption of parliamentary activities after the Easter recess on 22 April 2020, the House of Commons held its first virtual sitting. A hybrid model was adopted, with a limited number of parliamentarians present in the chamber and the majority following debate online. The hybrid parliament, however, was a short-lived endeavour and, in a controversial vote on 2 June, a majority of MPs supported the government's proposals to reinstate physical proceedings.

The shift to executive rule facilitated by the Coronavirus Act in effect sidelined Parliament during the pandemic, with there being limited opportunity for parliamentary oversight, and debate often occurring only after restrictions came into force. On 30 September, the House of Commons voted to extend the provisions of the Act for another six months, but the vote was preceded by uncomfortable accusations that in its use of emergency regulations the government had ridden roughshod over democratic procedures and undermined the role of Parliament in scrutinising legislation (HC Deb 30 September 2020).

Responding to pressure from parliamentarians to ensure Parliament would have a greater say in major rule changes and a vote on measures prior to implementation, the government capitulated somewhat in its position and agreed to do so, having secured the necessary parliamentary support for a six-month extension of the Act until March 2021 (HC Deb 30 September 2020).

As noted earlier, the response to the pandemic was driven not by the UK government but by a collective effort on the part of the UK and devolved governments. Many of the measures implemented by the UK government applied to England only, albeit the double role performed by the government created 
confusion when approaches diverged in the easing-of-lockdown phase. In the days after the initial lockdown in March, public approval of the government's handling of the pandemic reached a high of 72 per cent but gradually crumbled to 32 per cent at the end of October (YouGov 2020). The delayed response, weak communication, rising infection and death rates, and failure of government ministers and advisers to abide by the rules were oft-cited as contributing factors in the public's dwindling support for the government's handling of the pandemic (Waterson 2020).

\subsubsection{Devolved government action}

Working with the UK government, the devolved governments in Scotland, Wales, and Northern Ireland implemented a raft of measures within their competence jurisdictions. In early March, first ministers from the three administrations attended various COBRA meetings and the devolved governments had significant input in the creation of the four-nation Coronavirus strategy and Coronavirus Act. The Act conferred enhanced functions not only on UK government ministers but so too on ministers from the Scottish, Welsh, and Northern Irish governments. On 1 April 2020, the Scottish Parliament also passed its own legislation - the Coronavirus (Scotland) Act - to enshrine further provisions on various issues regarding housing provisions and evictions, judicial operations, and health-care regulations.

As at the national level, legislatures at the devolved level continued to operate. On 1 April, the Welsh Parliament was the first legislature to instate virtual proceedings, although a hybrid model was eventually rolled out. Akin to the House of Commons, the Scottish Parliament operated using a hybrid model of online and in-chamber debates and question times, while the Northern Irish Assembly continued to function in person, albeit with social distancing rules in place (Nicholson and Paun 2020).

In regard to preventative measures, the devolved governments took the lead in prohibiting gatherings, closing schools, and advising the use of face masks in public places, while the lockdown of 23 March was implemented in lockstep by all four governments. Despite limited financial resources, the devolved governments created financial support schemes for businesses, including loans and non-domestic rates relief. As early as 14 March, the Scottish government committed to a 75 per cent rates relief for the hospitality, leisure, and retail sectors from 1 April, as well as a GBP 80 million fund to provide grants to small businesses (Scottish Government 2020). Similarly, the Welsh government established the Economic Resilience Fund allowing small businesses to apply for rates relief as well as access to grants.

As discussed in the next section, the devolved governments also increased financial support for local authorities and worked with local stakeholders to harness local knowledge and innovation to curb the spread of the virus. Akin to the UK government, the devolved governments played a role in promoting advice 
and guidance related to preventing the spread of the coronavirus. The first ministers of Scotland and Wales, for instance, participated in daily press conferences broadcast on TV, while the first minister and deputy first minister of Northern Ireland held various joint and individual conferences.

Given the devolved governments' responsibility for health care, they were charged with ensuring that hospitals and health-care professionals were equipped with the necessary equipment. As noted, the UK government ultimately took the lead in securing PPE, but the devolved governments were responsible for the construction of field hospitals, conducting testing and tracing, and monitoring infection rates.

Despite the four-nation approach of March and April 2020, divergence appeared in May in the aftermath of the UK government's decision to ease the lockdown in England. In contrast with the jointly published Coronavirus Action Plan, each government published its own exit strategy for easing the lockdown. Divergence also emerged in regard to contact tracing and the adoption of digital approaches to making it more efficient. Both Northern Ireland and Scotland launched their own contact tracing apps in August and September, respectively, while a joint English and Welsh app was launched on 24 September.

As the second wave of Covid-19 began to rise in September, interaction between the UK and devolved governments increased, albeit it fell short of the unprecedented collaboration witnessed in March-April. The UK government's COBRA machinery was reconvened and localised restrictions followed in all four nations of the UK, as well as identical policies regarding the imposition on 22 September of a 22:00 curfew in bars and restaurants.

Divergence, however, appeared here too. The Scottish government was the first devolved administration to prohibit households meeting indoors in late September, and in early October, it introduced much tighter restrictions than any other government in the UK, including the closure of all bars, restaurants, and other social establishments in the central belt region for a period of three weeks. On 16 October, the Northern Irish government followed suit in closing pubs and restaurants for four weeks. It prohibited households from mixing, and went further by closing schools for a period of two weeks. Days later, on 19 October, the Welsh government announced a two-week lockdown from 23 October, requiring the closure of leisure facilities, places of worship and nonessential shops. By the end of October, restrictions remained in place in all three devolved territories.

The decentralised response to the pandemic in the UK unequivocally raised the profiles of the devolved governments. Responsibility for large swathes of public policy necessitated direct intervention by the Scottish, Welsh, and Northern Irish governments, each of which imposed and eased measures in their territories at their own pace. Tellingly, public perceptions of the handling of the pandemic saw the devolved governments repeatedly outpoll the UK government, including among inhabitants of England. In Scotland, despite the constitutional divide between pro- and anti-independence supporters, First Minister Nicola 
Sturgeon's handling of the pandemic was repeatedly rated higher than Prime Minister Boris Johnson's among both pro-independence and pro-union supporters (Panelbase 2020).

The devolved governments presided over similar problems as the UK government, including PPE shortages, low testing capacity, and a large number of deaths in both hospitals and care homes, but perceptions of how the governments managed the pandemic were dramatically different, with the devolved governments consistently polling higher than the UK government (Ipsos Mori 2020).

\subsubsection{Local government action}

In the UK, local government is a devolved matter and the organisation of local government and relations between local authorities and the devolved governments vary in all four nations (Jeffery 2006). In England, Scotland, and Wales, local councils are responsible for several jurisdictions severely affected by the coronavirus, including education, housing, and social care. ${ }^{3}$ Working and liaising with local authorities is thus the responsibility of each devolved government, and in the case of England, the UK government.

In all parts of the UK, governments issued guidance to local authorities and as such local government played an essential role in delivering and implementing measures endorsed by the respective governments. The essential role local government played in dealing with the impact of Covid-19 on education, social care, and protection for vulnerable people (such as the shielding initiative and food provision) necessitated significant increases in local government funding across all areas of the UK. Throughout the pandemic, governments in all four nations sought to address local government shortfalls and relieve financial pressures through multi-million-pound support packages for local authorities. By mid-August, the Welsh government had increased funding to local authorities to around GBP 500 million, while local authorities in Scotland benefited from additional spending powers and extra funding up to GBP 750 million. Likewise, the UK government increased local authority payments in England, but while financial packages of billions were rolled out to address local authority spending pressures, financial support for authorities in local lockdowns courted much controversy.

Introduced under Labour in 2009, but accelerated under the ConservativeLiberal Democrat coalition government (2010-2015), eight mayoral combined authorities exist in England, with responsibilities and powers over housing, social care, and transport. Recent research argues that the public profiles of directly elected mayors remain rather limited (Fenwick and Johnston 2020: 18), but the coronavirus pandemic undoubtedly raised the profile of some of these mayors. The relationship between these metro mayors and the central government, however, was fraught with difficulties, resulting in vehement opposition to aspects of the UK government's hyper-centralist approach in handling local outbreaks of the virus. 
In early October, for instance, in a letter to the Health Secretary, council leaders from Leeds, Liverpool, Manchester, and Newcastle criticised the UK government's side-lining of local government input and described the ensuing measures as 'confusing' and 'counter-productive' (BBC News 2020). For several days in October, media headlines were dominated by a clash between the Mayor of Greater Manchester Andy Burnham and the government and a threat of legal action by the former over the imposition of further restrictions in the area without local authority agreement. While some government ministers dismissed the row as party political (Burnham is a Labour politician), some Conservative MPs were vociferous in their support for the demands of mayors and council leaders (Kenny and Kelsey 2020). Despite government rhetoric that alluded to a collaborative working relationship with local government (HC Deb 28 April 2020), actions rarely matched the rhetoric. Centre-local relations were marked by imposition, not coordination.

\subsubsection{Intergovernmental relations}

There are various processes and structures for IGR in the UK, but the UK's experience with intergovernmental interaction since devolution has been 'largely bilateral, vertical and informal' (McEwen et al. 2012: 189). Various forums have been developed at both a multilateral and bilateral level, such as the Joint Ministerial Committee (JMC) which brings together all four governments. The JMC is the main body for IGR between the UK and devolved governments, but its functions are limited largely to knowledge-sharing and maintaining communication between the different governments rather than co-decision-making (Anderson 2021a).

In recent years, intergovernmental interaction in response to the UK's withdrawal from the European Union (EU) has increased, including the establishment of a new JMC (European Negotiations) to secure a pan-UK approach to EU withdrawal. In lieu of managing communal tensions on Brexit, however, the prevalence of governmental incongruence and competing constitutional visions have rendered IGR a source of tension (McEwen 2017): no pan-UK approach was secured prior to triggering the withdrawal process in March 2017, nor by the official withdrawal in January 2020.

In contrast to the strained relations that characterised IGR in the UK since the vote to leave the EU in 2016, the phase of initial response to the pandemic was marked by unprecedented levels of intergovernmental interaction. This culminated in a coordinated approach to lockdown in late March, preceded by the Coronavirus Action Plan which had all the hallmarks of an intergovernmental report. Coordination and collaboration between the different governments was short-lived, though, and appeared to come to an end in the easing-of-lockdown phase. As the uniform approach dissipated, so did intergovernmental interaction.

Despite the JMC's location at the apex of IGR structures, it was side-lined during the pandemic in favour of COBRA and newly created Ministerial 
Implementation Groups (MIGs). The first ministers of all three devolved nations participated in COBRA meetings, while MIGs, typically convened daily, brought together ministers and officials from all governments to respond to particular policy areas (health, public sector preparedness, economy, and international response) and serve as vehicles to facilitate communication and cooperation between the governments. This was also achieved through frequent meetings between officials from the various administrations and the chief medical officers and chief scientific advisers from different government departments and administrations.

The use of COBRA in lieu of formal IGR structures was easily justified given the emergency of the pandemic and the urgency of coordinating a response across the four parts of the UK. Tellingly, however, as the pandemic evolved and divergence in approach became apparent, COBRA was not convened, provoking criticism from the devolved governments that the UK government was seeking to 'sidestep difficult conversations' on diverging approaches (Savage 2020). In June 2020, the MIGs were disbanded and two new cabinet committees created: Covid-19 Strategy and Covid-19 Operations. Unlike MIGs, membership of the cabinet committees was not formally extended to the devolved governments, lending credence to the perception that intergovernmental interaction had returned to the strained relations of the pre-pandemic era.

Besides vertical interaction between the UK government and the devolved administrations, there was also evidence of horizontal relations between the three devolved administrations. This tended to focus on policy-specific issues, such as collaboration between the Scottish, Welsh, and Northern Irish finance ministers.

As has been pointed out elsewhere, even prior to the pandemic, IGR structures were in urgent need of 'a radical overhaul' (McEwen et al. 2020). Covid-19 nonetheless underlined the need for serious reflection at all levels of government on the importance of constructive relations and the efficacy of the UK's current institutional arrangements in facilitating them.

\subsubsection{Intergovernmental fiscal relations}

The UK economy was among some of the hardest hit of the world's developed countries as a result of the pandemic. In the period from April to June 2020, GDP contracted by 19.8 per cent and the UK economy fell by 21.5 per cent compared to 2019 (ONS 2020b). Since the easing of the lockdown in May, both GDP and the services, manufacturing and construction sectors saw significant improvement, even though the economy faces a long road to recovery, with unemployment levels forecast to increase with the cessation of the UK and devolved governments' economic intervention schemes and the prospect of continued disruption as a result of further lockdowns.

In a similar vein to the UK as a whole, the economic outlook for the devolved nations is also gloomy. A combination of limited economic activity and 
significantly increased public spending saw projections of a deficit in Scotland of 25-28 per cent of GDP, with potentially higher deficits in Northern Ireland and Wales due to their lower tax revenues and weaker economies (Phillips 2020). To ameliorate the economic impact of Covid, the UK Treasury increased funding via the Barnett formula (the block grant used to allocate funding to Scotland, Wales, and Northern Ireland) to all devolved governments. In March 2020, the Chancellor of the Exchequer announced a package of GBP 1.5 million of extra funding for the devolved administrations. As well as receiving increased Barnett funding, the devolved nations also benefited from increased funding under Barnett consequentials. ${ }^{4}$ Increases in health-care spending and other policy ambits due to the pandemic therefore resulted in billions of pounds in increased funds for the devolved administrations.

Notwithstanding increased levels of funding to the devolved governments, the pandemic spotlighted the limited fiscal capacity of the devolved governments, particularly in terms of borrowing. Ministers in all three devolved governments subsequently called for the further devolution of more fiscal levers, yet calls for additional powers went unheeded (Bol 2020). In line with the decentralised approach to managing the pandemic, economic support on the part of the UK government was not given with strings attached: the devolved governments were able to prioritise the funding as they saw fit.

\subsection{Findings and policy implications}

Covid-19 proved not only to be a major health crisis across the globe, but also the greatest social, economic, and political challenge the UK has weathered in the two decades since the establishment of devolved institutions in Scotland, Wales, and Northern Ireland. The implications of the decisions made to curb the spread of the deadly coronavirus are thus likely to reverberate down the years and decades to come. In particular, the evolution of the UK's pandemic response - from coordinated strategy executed in lockstep to free-form, sometimes fractious, divergence of approach - focused attention among politicians and the public alike on the system of UK territorial governance, something which doubtless will shape future debates, not least on the constitutional future of the UK.

In analysing the UK's management of the pandemic, it is clear to see that the actions of the various governments underlined the decentralised nature of the system. The clear division of competences between the UK and devolved governments eschewed controversy vis-à-vis competence jurisdictions and thus avoided any (further) unnecessary delays in reacting to the crisis. The collaborative approach seen at the beginning of the pandemic illustrated, on the one hand, the respect that exists for the division of responsibilities between different tiers of government, and, on the other, the presence of shared recognition of the importance of working together when faced with a momentous cross-border crisis.

Nevertheless, despite rhetoric on the part of the UK government and Whitehall machinery around supporting the autonomy of the devolved 
governments to make their own decisions within their competence briefs, the easing of the lockdown revealed frustration and a lack of understanding amongst some Westminster parliamentarians about the permissibility of the devolved governments to diverge from UK government policy.

At a wider level, this hints at the precarious nature of the federal spirit in the UK and how this precariousness has served to sustain - notwithstanding the federal logic of devolution that has taken root over the last two decades - the unitary mindset and majoritarian thinking that often characterises UK government decision-making processes (Anderson 2021b). This is compounded by the absence of an English executive and thus the UK government's double role as both a UK-wide and English-only government. During the crisis, the Prime Minister himself at times rejected the notion that his authority extends only to England (HC deb 11 May 2020), a stance reinforcing the notion that while devolution has entailed much change in the devolved nations, very little has changed at the centre.

A second intriguing finding, linked with the above, concerns the importance of local government in England in the absence of a separate English executive and legislature. Across the world, governments at all levels have had to respond to the pandemic, but it is local governments that have played an essential role in taking initiatives both within and outside the scope of their responsibilities to curtail and manage the spread of the virus.

In the UK, local governments unequivocally played a leading role in responding to the pandemic, but this was overshadowed and marginalised in England by the over-centralised approach of the UK government in its engagement with local authorities. Elected mayors in England made significant interventions in the debate on responding to the pandemic, though these often focused on critique of the government and calls for a more constructive approach on the part of the UK government in its interaction with local authorities. There are clear lessons to be learnt about taking a more proactive approach to local government engagement, specifically in harnessing local knowledge and using this to advantage in times of emergency and crisis. Rescheduled elections for most of the local mayoralties will take place in 2021; it may well be that the pandemic is a catalyst to further the debate on the devolution and strengthening of more powers for England's metro-mayors.

The experience of IGR during the pandemic reveals the urgency of reforming extant machinery to enhance communication and collaboration between the different governments. Amidst crisis, all four governments in the UK showed maturity in responding collaboratively to the pandemic, putting aside partisanship and political issues to focus on the good of the country. This, as the evidence in this chapter attests, swiftly unravelled as the devolved governments diverged from the UK government approach and offers telling proof of the need to overhaul the Westminster-centric model of IGR.

The history of devolution has been marked by willingness in Westminster to cede responsibilities to the devolved legislatures but hesitance to share power and thus work together. As much in normal times as in times of emergency, 
a genuine commitment to work collaboratively, underpinned by mutual trust, recognition, and respect, is important, not least in a plurinational democratic state. The response to the pandemic in the UK has demonstrated not just that a cooperative approach to IGR is possible, but that working together need not compromise the decentralised structures and dynamics of the territorial system.

There is no doubt that the coronavirus pandemic itself as well as the way it has been managed by the different tiers of government in the UK will have short- and long-term implications for contemporary British politics. Opinion polls throughout the crisis repeatedly recorded higher support for the devolved governments' handling of the pandemic than the UK government's, with levels of trust in the latter depleted as the pandemic evolved (Ipsos Mori 2020).

In January 2020, the UK left the EU after almost four years of political wrangling in both the UK and Brussels, but the constitutional impact of withdrawal remains in the balance and is compounded by the pandemic. The passage of the UK government's Internal Market Bill - designed to ensure harmonisation in trading rules and regulations across the UK - between September and December 2020 triggered significant controversy and was interpreted by the devolved governments as an assault on devolution. In contrast with the Coronavirus Act, which was passed with the consent of all three devolved legislatures, legislative consent for the Internal Market Bill was refused by all three devolved legislatures. At the same time, polling on Scottish independence has begun to suggest that there may be a sustained majority in favour of independence, with evidence pointing to the Scottish government's handling of the pandemic as a key catalyst for growing support.

As has been pointed out elsewhere, there is evidence that nationalist forces around the globe have sought to 'weaponise' the coronavirus pandemic to further their aims (Woods et al. 2020). The UK is no exception. However, while there is no doubt that pro-independence supporters in Scotland are likely to point to the Scottish government's handling of the pandemic as proof of Scotland's ability to be an independent country (notwithstanding some complaints about its government's handling of the crisis), unionists have been equally proactive in underlining the might of the Union in responding to the pandemic. Covid-19 has not merely introduced new dynamics in contemporary British politics but has already begun to redefine well-entrenched territorial debates.

\section{Notes}

1 Figures on the overall death toll from Covid-19 vary and are counted in three different ways: deaths within 28 days of a positive result (this is used for government figures), death certificate mentions of Covid-19, and deaths over and above the usual number at a particular time of year. As of 31 October 2020, 46,555 deaths occurred within 28 days of a positive result, almost 59,000 death certificates stated Covid-19 as the cause of death, and more than 67,000 excess deaths had occurred over and above the yearly average.

2 The Sewel Convention states that the UK Parliament 'will not normally legislate with regard to devolved matters without the consent' of the devolved institutions. 
3 Local governments in Northern Ireland have fewer responsibilities than elsewhere in the UK, with no policy responsibility for education or social care.

4 Barnett consequentials refer to the mechanism whereby any increase in public expenditure in England generates increased funding for the devolved administrations.

\section{References}

Anderson, Paul. 2021a. 'Plurinationalism, Devolution and Intergovernmental Relations in the UK', in Y. Fessha, F. Palermo and K. Kössler (eds), Intergovernmental Relations in Divided Societies: A Comparative Analysis. London: Palgrave MacMillan. Forthcoming.

Anderson, Paul. 2021b. 'Spain and the United Kingdom: Between Unitary State Tradition and Federalisation', in S. Keil and S. Kropp (eds), Emerging Federal Models in the Post-Cold War Era. London: Palgrave MacMillan. Forthcoming.

BBC News. 2020. 'Covid-19: Council Leaders Send Matt Hancock Action Plan', 7 October. Bol, David. 2020. 'Kate Forbes Joins Forces with Welsh and Northern Irish Counterparts in Plea for Powers', The Herald, 8 July.

Fenwick, John and Lorraine Johnston. 2020. 'Leading the Combined Authorities in England: A New Future for Elected Mayors?', Public Money \& Management, 40(1): 14-20.

Griglio, Elena. 2020. 'Parliamentary Oversight under the Covid-19 Emergency: Striving against Executive Dominance', The Theory and Practice of Legislation, 8(1-2): 49-70.

Hansard Society. 2020. Statutory Instrument Tracker, https://www.hansardsociety.org.uk/ services/statutory-instrument-tracker (last accessed on 10 November 2020).

HC Deb. 11 May 2020, vol 676, col 33.

HC Deb. 19 March 2020, vol 673, col 1178.

HC Deb. 28 April 2020, vol 675, col 204.

HC Deb. 30 September 2020, vol 681, col 389.

Ipsos Mori. 2020. COVID-19 Polling BBC Scotland. 26 May.

Jeffery, Charlie. 2006. 'Devolution and Local Government', Publius, 36(1): 57-73.

Johnson, Boris. 2020a. Prime Minister's Statement on Coronavirus (COVID-19), 16 March. Johnson, Boris. 2020b. Prime Minister's Statement on Coronavirus (COVID-19). 10 May.

Kenny, Michael and Tom Kelsey. 2020. 'Devolution or Delegation? What the Revolt of the Metro Mayors over Lockdown Tells Us about English Devolution', LSE British Politics and Policy. 12 November.

McDonnell, Adam. 2020. 'Public Support for a Two-week Lockdown Persists', YouGov, 30 October.

McEwen, Nicola. 2017. 'Still Better Together? Purpose and Power in Intergovernmental Councils in the UK', Regional and Federal Studies, 27(5): 667-90.

McEwen, Nicola, Wilfried Swenden and Nicole Bolleyer. 2012. 'Introduction: Political Opposition in a Multi-Level Context', The British Journal of Politics and International Relations, 14(2): 187-97.

McEwen, Nicola et al. 2020. 'Intergovernmental Relations in the UK: Time for a Radical Overhaul', The Political Quarterly, 91(3): 632-40.

Mitchell, James, 2009. Devolution in the UK. Manchester: Manchester University Press.

Nicholson, Elspeth and Akash Paun. 2020.'Devolved Legislatures: How Are They Working in the Coronavirus Lockdown?', Institute for Government, 24 November.

Office of National Statistics (ONS). 2020a. Population and Migration.

Office of National Statistics (ONS). 2020b. 'Coronavirus and the Impact on Output in the UK Economy: June 2020'.

Panelbase. 2020. 'How have Johnson and Sturgeon Coped with Covid-19?', 11 July. 
Phillips, David. 2020. 'Scotland's Implicit Budget Deficit could be around 26-28\% of GDP in 2020-21', Institute for Fiscal Studies, 26 August.

Sandford, Mark. 2020. 'Giving Power Away? The "De-Words” and the Downward Transfer of Power in Mid-2010s England', Regional and Federal Studies, 20(1): 24-46.

Savage, Michael. 2020. 'Boris Johnson Has Not Hosted a Cobra Emergency Committee for over a Month', The Guardian, 14 June.

Select Committee on the Constitution. 2020. Constitutional Implications of Covid-19. 2 December.

Scottish Government. 2020 ، ‘320 million Package of Support for Businesses'. 14 March.

Waterson, Jim. 2020. 'Public Trust in UK Government over Coronavirus Falls Sharply', The Guardian, 1 June.

Woods, Eric, et al. 2020. 'COVID-19, Nationalism, and the Politics of Crisis: A Scholarly Exchange', Nations and Nationalism. https://doi.org/10.1111/nana.12644 (accessed on 20 February 2021).

YouGov. 2020. 'Covid-19: Government Handling and Confidence in Health Authorities', 17 March. 